\title{
The rationale for the development of a method for assessing the roof conditions of mine workings in the conduct of actual mining using the method of geoinformation analysis
}

\author{
Alexander Abramovich ${ }^{1}$, Yuri Stepanov ${ }^{2}$, and Jurgen Kretschmann ${ }^{3}$ \\ ${ }^{1}$ T.F. Gorbachev Kuzbass State Technical University, 650000, 28 Vesennya str., Kemerovo, Russian \\ Federation \\ ${ }^{2}$ NFI Kemerovo State University, 654000, pr. of metallurgists 19, Novokuznetsk, Kemerovo region, \\ Russian Federation \\ ${ }^{3}$ Technische Hochschule Georg Agricola (THGA), Bochum, Germany
}

\begin{abstract}
This article considers the need of developing the method for evaluating the condition of excavation roof using the method of geoinformation analysis. The article also describes the existing research and roof control methods and analyzes their advantages and disadvantages. On the basis of this analysis the authors of the article establish the requirements for the method developed. The authors suggest using the geoinformation technologies for modeling, analyzing and evaluating excavation roof condition. We compile a list of tasks which are to be accomplished to develop the method. The paper presents the list of information objects, the database and the properties of these objects. The approach to database implementation is chosen. The database structure is presented. The article also describes the technology of geospatial data analysis, various sections data required for the development evaluation method. The analysis and selection of software for 3D modeling are made up, and 3D models of excavation sites are built.
\end{abstract}

\section{Introduction}

At the present time coal mining is rapidly increasing. The use of various technologies of coal extraction places increasingly high demands on equipment and connections for reliability, performance and a number of other criteria. Replacement of old mine equipment by modern high-tech equipment allows to solve many production applications, the most important of which is productivity gains taking into account issues of safety of mining operations. Modern equipment incorporates a large number of different sensors that allow analyzing the state of equipment and technological processes, but this is not enough to ensure safe working conditions. In the sphere of mining safety, there are many unsolved problems, one of which is the assessment of stress-strain state of a mountain range. The

\footnotetext{
${ }^{1}$ Corresponding author: abramovich_sanja@,rambler.ru
} 
process of coal extraction is a dynamic process, as a result of which the stress-strain state of rocks is redistributed in the districts of coal face. Mine workings require timely surveys and final report on the stage of working. The need for monitoring and assessment of status of stress-strain state of rocks occurs with increasing depth of mining coal seams. On the basis of obtained data geoinformation models of mining are built. Despite the wide choice of mountain geoinformation systems, there is lack of facilities of geoinformation analysis of rocks status [1]. In this regard, it is proposed to use the method of geometry analysis of occurrence of emergency situations for timely executive decision-making. This will allow selecting equipment for miming operations, which in turn will contribute to safe and highly productive extraction of mineral products.

\section{Materials and methods}

There are plenty of research methods of roof conditions, the most common are: visual monitoring, georadiolocation, et al. [2-6]. Table one presents the comparative analysis of the most common research methods of roof conditions in underground mining workings.

Table 1. Advantages and disadvantages of the existing research methods and monitoring of roof displacement condition of mine workings.

\begin{tabular}{|c|c|c|}
\hline Method & Advantages & Disadvantages \\
\hline \multirow[t]{4}{*}{ Visual monitoring } & $\begin{array}{l}\text { Assessment by workers of roof } \\
\text { conditions of mine workings at } \\
\text { the place of installation of } \\
\text { deep bench marks. }\end{array}$ & $\begin{array}{l}\text { The inability of permanent } \\
\text { monitoring of roof conditions. }\end{array}$ \\
\hline & Ease of use. & $\begin{array}{l}\text { The inability to analyze the stress- } \\
\text { strain state of roof of mine } \\
\text { workings. }\end{array}$ \\
\hline & \multirow[t]{2}{*}{ Simplicity of installation. } & $\begin{array}{l}\text { The great influence of human } \\
\text { factors. }\end{array}$ \\
\hline & & $\begin{array}{l}\text { There are no accurate readings of } \\
\text { the stress-strain state of roof of mine } \\
\text { workings. }\end{array}$ \\
\hline \multirow[t]{5}{*}{ Georadiolocation } & $\begin{array}{l}\text { Visualization of scanned roof } \\
\text { on radargram. }\end{array}$ & $\begin{array}{l}\text { The inability to analyze the stress- } \\
\text { strain state of roof of mine } \\
\text { workings. }\end{array}$ \\
\hline & $\begin{array}{l}\text { The ability to bind the radar } \\
\text { gram to the pickets of the } \\
\text { mine. }\end{array}$ & $\begin{array}{l}\text { There are no accurate readings of } \\
\text { the stress-strain state of roof. }\end{array}$ \\
\hline & $\begin{array}{l}\text { High speed of radar scan of } \\
\text { roof. }\end{array}$ & $\begin{array}{l}\text { The inability of permanent } \\
\text { monitoring of roof conditions. }\end{array}$ \\
\hline & \multirow{2}{*}{$\begin{array}{l}\text { The ability to analyze changes } \\
\text { of roof conditions on the } \\
\text { scanned areas. }\end{array}$} & $\begin{array}{l}\text { There is no database of radar grams } \\
\text { of roof conditions of mine workings. }\end{array}$ \\
\hline & & Low current capacity. \\
\hline \multirow[t]{3}{*}{$\begin{array}{l}\text { Survey of collared } \\
\text { holes by videoimage } \\
\text { endoscopy }\end{array}$} & $\begin{array}{l}\text { Identification of } \\
\text { decompactification zones and } \\
\text { rock jointing of massif. }\end{array}$ & $\begin{array}{l}\text { The inability of permanent } \\
\text { monitoring of roof conditions. }\end{array}$ \\
\hline & $\begin{array}{l}\text { Understanding the } \\
\text { composition of massif in the } \\
\text { study area. }\end{array}$ & $\begin{array}{l}\text { The inability to analyze the stress- } \\
\text { strain state of roof of mine } \\
\text { workings. }\end{array}$ \\
\hline & & $\begin{array}{l}\text { The great influence of human } \\
\text { factors. }\end{array}$ \\
\hline
\end{tabular}

On the basis of data in Table 1, it may be concluded, that all existing methods of analysis have a number of disadvantages, the most important of which are: the inability of 
permanent monitoring of roof conditions, the inability to analyze the stress-strain state of roof of mine workings, the great influence of human factors.

On the basis of a comparative analysis of existing methods for assessing the roof conditions of mine workings, it can be concluded that the existing methods for monitoring the roof conditions are outdated and their use as the basic monitoring method is not relevant and not rational, but it is possible to use them as additional ones.

In addition to the considered methods for monitoring the status of stress-strain state, there are methods [7-15], often based on the use of geographic information systems. Geoinformation technologies that are part of geographic information systems (GIS) are used for the analysis of geospatial data.

On the basis of GIS, such tasks as the collection, storage, presentation of spatial information, geoscience analysis, visualization and modeling of geospatial data are solved [10].

There is no ready-made complex and method of geo-information analysis and evaluation of roof conditions of mine workings which confirms the relevance of the problem under consideration.

Thus, one of the tasks to ensure the safety of mining and improve the performance of mining equipment is a development of method of geo-information analysis and evaluation of roof conditions of mine workings.

The following requirements are imposed on the developed method:

1. The possibility of permanent monitoring and analysis of roof displacements of mine workings.

2. Introduction of numerical methods to eliminate the human factor.

3. The existence of prediction methods of roof displacements.

To develop a method it is necessary to solve the following tasks:

1. Makeup of data objects that are necessary for building 3D models of mine working.

2. Development of a database for storing information about the state of massif.

3. Selection of software for building 3D models of mine workings.

4. The choice of equipment and technology for the organization of monitoring the stress-strain state of rock formation.

5. Development of a methodology for modeling the stress-strain state of rock massif in different geological conditions.

6. Development of methods for geo-information analysis of the results.

The following information is required to build $3 \mathrm{D}$ models and to store data on roof displacements of mine workings:

1. Indications and time of their fixation with reference to pickets and installation sites.

2. Data on mine divisions, such as: the name of the division, isohyps, type of violation, the intersection of exploration wells with the seam, the seam thickness, etc.

3. Data from the powered support units.

Modern powered supports have many different built-in sensors, one of which allows evaluating the stress-strain state of massif. In the future, it is planned to investigate the analysis of the stress-strain state of massif on the basis of data from the powered support units.

\section{Realization}

It is necessary to use databases using the object-oriented approach of Entity Framework, built on the basis of the platform .Net. The database structure is shown in Figure 1. 


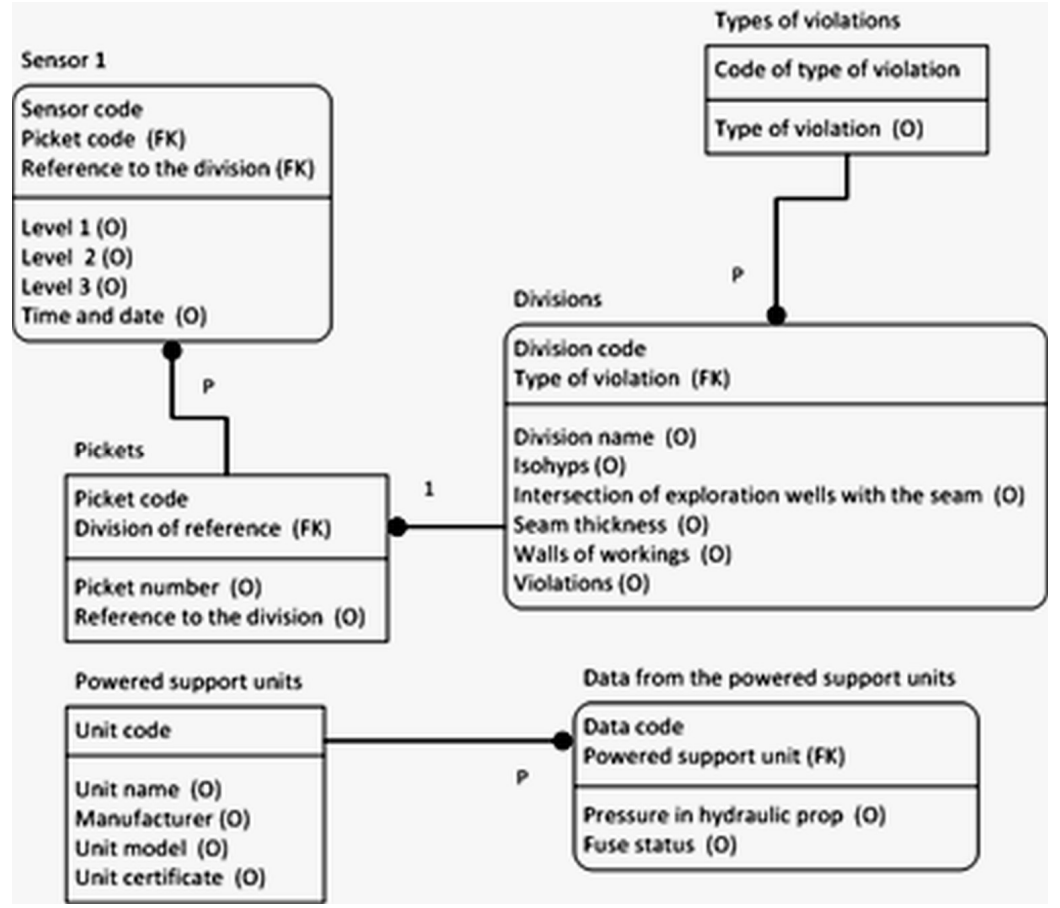

Fig.1. The database structure.

Data warehouses are formed on the base of the collected and calculated data. As a method of analysis, it is advisable to use OLAP-technologies and their varieties (HOLAP, MOLAP), which allow, based on the collected data (raw data) and slicing at selected points, to obtain new knowledge about the conditions of the massif. Through this, it is possible to obtain new dependencies characteristic of this block.

To build 3D models of mine workings, you can use various software applications with built-in 3D modeling tools. Based on the specificity of the visualization of geospatial data, the following requirements are imposed on the 3D modeling program:

1. The existence of the analysis module by the finite element method.

2. Ability to work with triangulated grids.

3. Rendering.

4. Animating a model.

For modeling of the stress-strain state of rock formation in the vicinity of the extraction work, taking into account the changing geological conditions, the software analysis was carried out. It is presented in Table 2 .

Table 2. Comparative characteristics of $3 \mathrm{D}$ modeling programs.

\begin{tabular}{|c|c|c|c|c|}
\hline & AutoCAD & T-Flex CAD & KOMPAS-3D & FreeCAD \\
\hline License type & $\begin{array}{c}\text { Training version, } \\
\text { limited }\end{array}$ & $\begin{array}{c}\text { Training version, } \\
\text { limited }\end{array}$ & $\begin{array}{c}\text { Training version, } \\
\text { limited }\end{array}$ & Freeware \\
\hline Rendering & + & + & + & + \\
\hline $\begin{array}{c}\text { Analysis by the finite } \\
\text { element method }\end{array}$ & + & + & + & + \\
\hline Animating a model & + & + & + & + \\
\hline Work with triangulated & + & - & - & + \\
\hline
\end{tabular}




\begin{tabular}{|c|c|c|c|c|}
\hline & AutoCAD & T-Flex CAD & KOMPAS-3D & FreeCAD \\
\hline grids & & & & \\
\hline
\end{tabular}

Analysis of the software (SW) concluded that to meet the challenges of modeling of massif, AutoCAD or FreeCAD can be used. The work will use FreeCAD, as it meets all the requirements and applies to FreeWare. The triangulated block and the constructed 3D models of the block are presented in Figures 2, 3, 4.

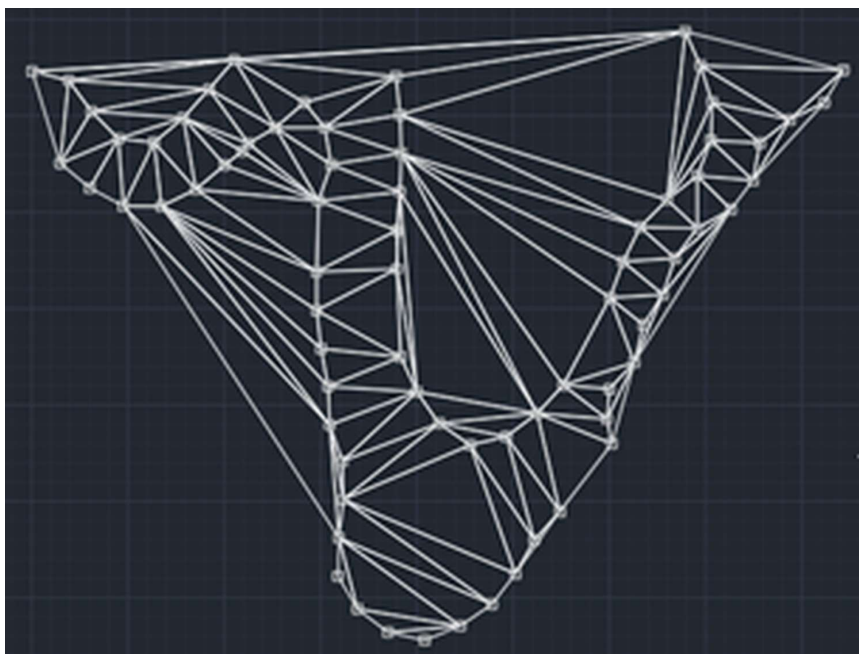

Fig.2. Triangulation of block.

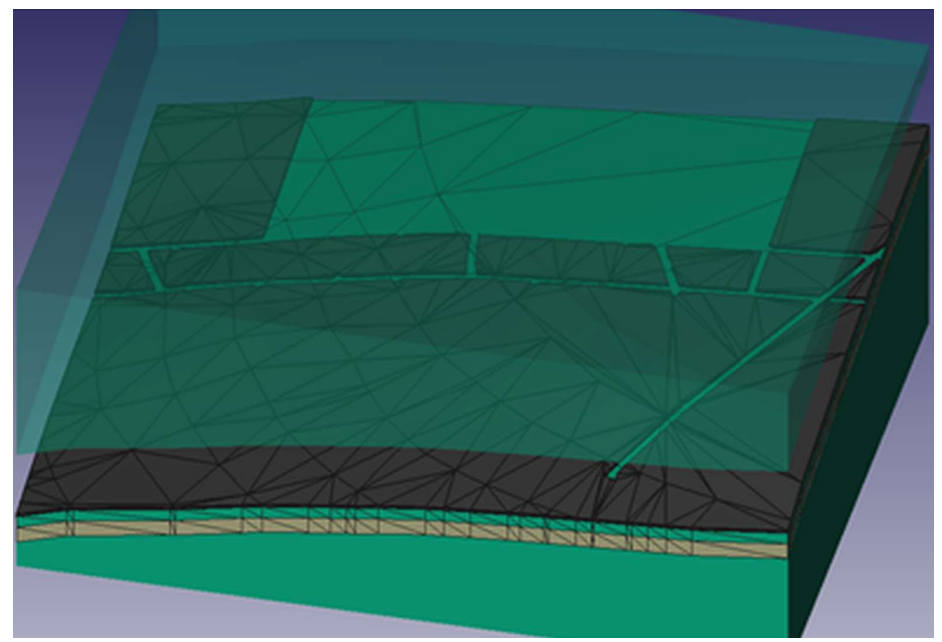

Fig. 3. 3D - model of the block. Isometric view. 


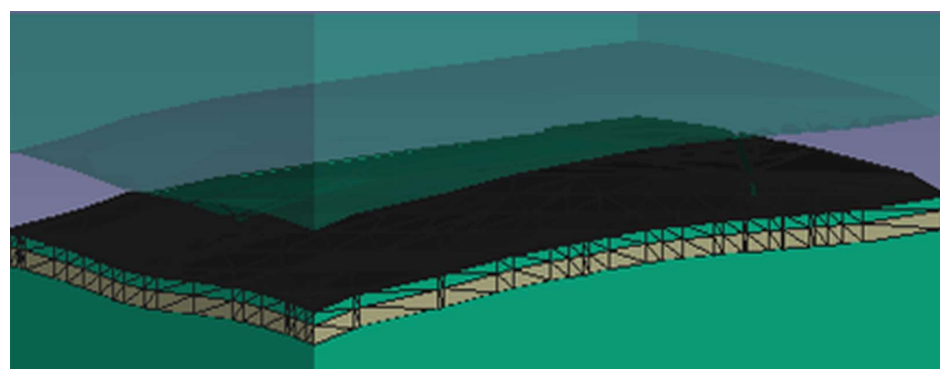

Fig.4. 3D - model of the block. Front view.

\section{Conclusion}

As a result of this work, prerequisites were created for the development of a method for assessing the roof conditions of mine workings in the conduct of actual mining using the method of geoinformation analysis. A list of tasks that need to be solved for the development of the method was compiled. A database structure has been developed, which is necessary for modeling mine workings, automatisation the construction of $3 \mathrm{D}$ - model of blocks and modeling the stress-strain state of rock formation. A 3D modeling program was selected in which models of blocks were constructed.

The development and application of the method for assessing the roof conditions of mine workings in the conduct of actual mining using the method of geoinformation analysis will improve the safety of mining, increase labor productivity and reduce the time for modeling, analysis and assessment of roof conditions of mine workings.

\section{References}

1. M. Satya, O. Anurag, M. Sachin, Nat. Conf. OSGIS-2015, 150 (2015)

2. G.L Feofanov, Urgalugol JSC 3, 18 (2017)

3. C. Zhao, Y. Zhang, G. Zhang, J. Li, S. Ma, Sensors, 17, 1044 (2017)

4. J. Doherty, A. Hasan, G. Suazo, A. Fury, Can. Geotech. J., 52, 1901 (2015)

5. E. Lawson, D. Tesarik, M.Larson, H. Abraham, Int. Conf. GCM, 35, 26 (2016)

6. Y. Zhao, N. Zhang, G. Si, Sensors, 16,112 (2016)

7. Y. Mustafa, A. Ahmet, O. Muharrem, K. Bayram, Y. Hayati, Int. J. E. Res. Tech., 7, 199 (2018)

8. M. Larson, D. Tesarik, J.Seymour, R. Rains, Inf. Circ., 151,253 (2000)

9. Z. Zhang, J. Bai, Y. Chen, S. Yan, Int. J. Rock Mech. Min. Sci., 80, 1 (2015)

10. J. Blachowski, A. Chrzanowski, A. Szostak-Chrzanowski, Conf. Int. Mine Surv. C. Aachen, 15, 529 (2013)

11. A. Verma, D. Deb, Int. J. of Geomech., 13, 181 (2013)

12. Y. Lu, W. Yang, J. of Central South. Univ., 20, 1397 (2013)

13. A. Chanyshev, I. Abdulin, J. of Mining Sci., 50, 18 (2014)

14. V. Vaziri, J. Hamidi, A. Sayadi, Environ. Earth Sci., 77, 1 (2018)

15. A. Iannacchione, T. Bajpayee, L. Prosser, Min. Eng., 59, 47 (2007) 